\title{
Clearing the Field: How do Presidential Primary Candidates Win Big on Super Tuesday?
}

\begin{abstract}
In presidential primaries, Super Tuesday elections play a significant role in winnowing candidate fields and establishing nomination frontrunners. Despite their importance, scholars know little about why and how candidates win or lose the states comprising these events. This study explores which factors help explain candidate performance in Super Tuesday primaries between 2008 and 2016 . Using pooled crosssectional time-series analysis, the results indicate three key drivers of Super Tuesday success: candidate viability, public attention, and media attention. These findings imply that while there are similarities between Super Tuesdays and the broader explanations of presidential primary results, there are opportunities for upstart candidates to improve their performance vis-à-vis frontrunners, particularly since winning prior primaries or caucuses are not a uniquely significant predictor in our models. Future research should explore the interrelatedness of these three critical factors as well as how campaigns strategically attempt to influence Super Tuesday voters.
\end{abstract}

C. Douglas Swearingen

John Carroll University

cswearingen@jcu.edu

\section{Keywords}

Campaigns, elections, presidential primaries, public attention, Google Trends, media attention, polling, fundraising, endorsements

\section{Introduction}

On February 5, 2008, 23 states participated in a Democratic Party presidential primary or caucus pitting Barack Obama against Hillary Clinton. With nearly 1,700 delegates at stake, this "Super Duper Tuesday" event had the potential to alter the course of what had been a tight battle for the party's nomination (Schneider 2007). Instead, the candidates split the delegates (with a slight edge for Obama), the popular vote (with a slight edge to Clinton), and the number of states won (with a slight edge for Obama). That same day, Republicans in 21 states voted for their preferred presidential candidate. Despite a narrow popular vote win by John McCain over Mitt Romney, McCain won nearly two-thirds of the available delegates and cemented his status as the party's front-runner for the nomination (Sullivan and Luo 2008).

There a few ways in which Super Tuesdays play a significant role in the presidential nomination process. They provide information to voters by signaling a candidate's momentum and viability, as happened in the 2008 Democratic primary, which can result in increased fundraising (Steger 2008). They can serve to winnow the field of candidates, as those who perform poorly - in terms of both delegates won and expectations - may drop out of the race (Norrander 2000). Finally, they may signify the end of a competitive nomination battle, as exhibited in the 2008 GOP race.

Despite the importance of Super Tuesdays, elections scholars know little about why and how candidates win or lose the states comprising these events, nor do we know whether they 
empirically differ from other primary election events, such as Iowa, New Hampshire, or the overall contested primary vote (CPV). This study attempts to fill this gap by first detailing the role these events play in the nomination process. We then explore whether traditional explanations of presidential primary outcomes apply to this context. Using pooled crosssectional time-series analysis, we identify three key drivers of Super Tuesday performance: viability, public attention, and media attention. These results suggest that while there are similarities between Super Tuesdays and the broader explanations of presidential primary results, there are opportunities for upstart candidates to improve their performance vis-à-vis frontrunners.

\section{Super Tuesday Primaries}

Super Tuesdays are largely a product of the "front-loading" phenomenon in presidential primaries. State legislators noticed the amount of attention given to Iowa and New Hampshire, both by presidential candidates and the media, as well as the reality that post-McGovern-Frasier Commission presidential nominations were being settled early in the process, and decided to move their primary or caucus to earlier in the calendar (Ridout and Rottinghaus 2008). The desire to attract attention and play a greater role in determining presidential nominees led some states to create the first media-designated Super Tuesday in 1984 (Stanley and Hadley 1987), when five states held primaries and another four held caucuses (Mayer and Busch 2004).

The 1988 primary marked an important strategic shift in Super Tuesdays: the creation of a regional election. After the Reagan general election victories in 1980 and 1984, southern states were frustrated by the Democratic Party's lack of success in general elections, particularly in their region, the perceived inability of a conservative Democrat to win the party's nomination, and the amount of attention given to Iowa and New Hampshire. In what Hadley and Stanley $(1989,23)$ describe as an "organizational success", every southern state agreed to hold their primary or caucus on the same day. Combined with some non-southern states, one-third of all delegates were up for grabs that day, an event spanning 16 states, 121 media markets, and 171 congressional districts (Norrander 1992; Hadley and Stanley 1989). While scholars found little evidence that the southern states were effective in their goals (Hadley and Stanley 1989; Norrander 1992), the idea of regional primary events did not go away, with 1996's "Yankee Primary" and "Big 10 Primary" serving as examples of geographic regions attempting to influence presidential nomination outcomes (Ridout and Rottinghaus 2008). If anything, Super Tuesdays became bigger after 1988, culminating in the 2008 event that involved close to two dozen states between the two major parties.

The combination of front-loading and Super Tuesdays has implications for the type of candidates that can win a primary. Front-loaded primaries require candidates to raise more money during the invisible primary - the time between when candidates announce they are running and the Iowa caucuses - in order to have a large enough campaign organization in multiple states at once. As Mayer and Busch (2004) point out, this amounts to an entrance fee 
just to run for president, one that most candidates are unable to afford (Norrander 2000). Finally, Hadley and Stanley (1989) present compelling evidence that the 1988 southern state strategy aimed at nominating a more moderate Democrat backfired, arguing that the presence of multiple candidates with southern roots helped keep the more liberal Michael Dukakis campaign alive as Jesse Jackson and Al Gore split the southern delegate pool. Furthermore, Gore's candidacy was only viable in the South; with every state in the region voting on Super Tuesday, there were no other winnable states on the calendar, thus depriving him of receiving any momentum later in the campaign.

Despite the increased size and frequency of Super Tuesdays (Norrander 2010), elections scholars have spent little time exploring who wins the states comprising these events and why. Many of the studies focusing on Super Tuesday look at the phenomenon from the vantage point of the state and/or region. For instance, states tend to receive more media attention when they host a primary earlier in the process (Ridout and Rottinghaus 2008), there are not too many other states holding a primary or caucus on the same day (Mayer and Busch 2004), and when more delegates are at stake (Gurian 1993; Norrander 1992). Counter to the southern state strategy of 1988, Ridout and Rottinghaus (2008) find that geographic proximity - i.e., the regional primary - does not significantly increase media attention for the individual state (Gurian 1993). This suggests that if states want to receive more media and candidate attention, states would be wise to avoid holding a primary on Super Tuesday.

States are not the only entity looking for increased media attention; candidates know that unless the media covers their campaign, they have little chance of winning the nomination. This is the reality of a sequential primary process and stems from the uniqueness of Iowa and New Hampshire receiving their own day in the spotlight. Candidates who perform better in these two states generally do better in Super Tuesday states. As Redlawsk et al. (2011) find, 25 percent of 2008 Super Tuesday voters said that winning Iowa was important; another 25 percent said the same of New Hampshire. The clear implication is that Super Tuesdays favor frontrunners and candidates with significant momentum coming out of the early states (Norrander 2010). An example of the latter is the 1984 candidacy of Gary Hart. Hart finished a surprising second place in Iowa before rattling off victories in New Hampshire and Vermont. These victories increased his name recognition among Super Tuesday voters from 50 percent to 90 percent (Bartels 1989). Indeed, even in 1988 as southern states were hoping for candidates to ignore the early states, candidates spent more time in Iowa and New Hampshire than all the southern states combined (Hadley and Stanley 1989).

Studies focusing on Super Tuesday results typically include one of two nomination cycles: 1988 or 2008 due to the novelty factor (1988) or the number of states involved (2008). There is consensus that, while Super Tuesday state results can be volatile (Norrander 1992), they often boil down to a few key factors: viability and momentum. Viability, or the likelihood that a candidate can win, is the main factor, as it can supersede momentum. Presidential primary voters can be strategic; they will vote for the candidate they believe will win the primary and/or who 
they perceive has the best chance of winning in November. In the 1988 primaries, 10 percent of Republicans and 9 percent of Democrats voted for their second choice for this reason (Abramson et al. 1992). The importance of viability played a role in John McCain's 2008 GOP victory, in part due to the lack of a strong front-runner. Republicans simply viewed him as the most electable candidate (Redlawsk, Tolbert, and Donovan 2011).

The 1988 Democratic primary was somewhat similar in that Michael Dukakis was only narrowly ahead in delegates heading into Super Tuesday. In this case, however, Norrander (1992) finds that momentum played an important role in his performance as his support increased by 17 percent among voters aware of his New Hampshire primary victory. Interestingly, preferences among Republicans were stable coming out of the early primaries; George H. W. Bush effectively wrapped up the nomination in part because voters did not perceive his rivals to be viable. One implication of Bush's victory is that clear front-runners are favored unless there is significant momentum behind a candidate (Mayer and Busch 2004). Bartels (1989) argues that the closest example of this came in 1984 when Gary Hart overperformed in every Super Tuesday state due to the momentum he earned from his second-place finish in Iowa. Still, while Hart came close to beating Walter Mondale, momentum alone was not enough.

\section{The Importance of Super Tuesdays \& Their Distinction from Other Presidential Primaries}

Super Tuesdays play an instrumental role in determining who wins a party's presidential nomination, the effects of which are apparent through recent presidential primary history. Some candidates, such as George H.W. Bush in 1988, are able to effectively end the race by dominating the Super Tuesday primaries. For others, like Michael Dukakis, Super Tuesday is about performing well enough to justify moving on to the next round of primaries (Norrander 2010, 1992). In this lens, Super Tuesdays are not just about establishing a clear winner. They are an attrition game that can have clear losers; candidates who perform poorly typically drop out of the race, effectively winnowing a party's candidate field and clarifying the front-runner. Thus, Super Tuesdays speed up the nomination process after the early primaries and caucuses (Norrander 2000).

Super Tuesdays are also unique from the early primaries and caucuses. Due to the sequential nature of the nomination cycle, candidates are able to focus on a couple of states, knowing that a poor performance in Iowa or New Hampshire can end their candidacy. But in the lead up to a Super Tuesday, they must choose which states they visit and run ads in (Wendland 2017). Candidates who win one or more early states receive significantly more media attention (Bartels 1993) and are seen as more viable candidates (Kenney and Rice 1984). These realities provide Super Tuesday voters with more information about the surviving candidates as well as an opportunity to alter the state of the race for subsequent voters. 
This distinction between the early primary/caucus states and Super Tuesday, combined with frontloading, allows for different types of candidates to win states. Wendland (2017) notes that presidential primary candidates are strategic in their use of campaign resources, messaging, and advertising in attempting to win delegates throughout the primary season. This includes their preparations for Super Tuesday states, as candidates understand that success in these events are paramount to both winning the nomination and staying in the race. Unlike in the early states, it is more difficult for a campaign to achieve parity in candidate visits, although well-resourced candidates may have a significant presence in the Super Tuesday states. As such, upstart candidates who win one of the early states but lack the financial resources of a frontrunner can perform well in places where their message is well received. For instance, after winning the 2008 GOP Iowa caucuses, Mike Huckabee was able to win some southern states (Alabama and Georgia) despite trailing John McCain and Mitt Romney in national polling and fundraising. In 2012, Rick Santorum won a geographically diverse set of contests - Alaska, North Dakota, Oklahoma, and Tennessee - despite significantly trailing Mitt Romney in delegates won heading into that Super Tuesday.

\section{What is Super Tuesday \& What Explains Super Tuesday Performance}

While the term "Super Tuesday" is frequently cited in media and academic sources, there appears to be no standard definition. One key reason for studying Super Tuesdays is because they are winnowing events in an attrition game. If scholars spend time analyzing Iowa and New Hampshire results and their relation to shrinking the pool of candidates, it makes sense that we understand other important junctures that can have a similar effect. The problem with studying Super Tuesdays in this lens is that the term itself is not precisely defined by scholars; it is more of a label used by the media and political pundits dating back to at least the 1976 presidential primaries (UPI 1976). The size and timing of these electoral events change with the political cycle, but there are some common characteristics of what constitutes the media giving a set of primaries this label.

First, there can be multiple Super Tuesdays in a nomination contest. Norrander (2015) notes that in recent presidential primaries, the initial Super Tuesday does not completely end the nomination contest. This extended competitive phase allows additional primaries/caucuses to winnow further the candidates, including additional Super Tuesday events. For instance, the 2016 contests had three media-designated Super Tuesdays: March 1 (Washington Post 2016), March 15 (Bradner 2016), and yet a third on April 26 (Collinson 2016). Sometimes these Super Tuesday events are labeled slightly differently, such as "Super Duper Tuesday" in February 2008, when close to two dozen states held either a primary or caucus (Schneider 2007). Each cycle since 1976, with the exception of 1988, had more than one competitive Super Tuesday (although the term "Super Tuesday" was not formally used in 1976) (see Putnam 2009a). It is important to note that each cycle does not necessarily have multiple Super Tuesdays, but any working definition of Super Tuesday must allow for multiple occurrences in the same cycle. 
The second characteristic of Super Tuesdays is that the media-christened events usually included at least five states. The final Super Tuesday of the 1984 Democratic primary included five states: South Dakota, New Mexico, West Virginia, California, and New Jersey (Church 1984). Even the "Mini-Tuesday" in February 2004, consisted of seven states. The possible exception to this characteristic is 2016's Super Saturday, during which Democratic voters in three states and Republican voters in four states went to the polls. Under this condition, there has been at least one Super Tuesday in each presidential primary cycle since 1976 (see Putnam 2009). Thus, while it is possible that a cycle could not have such an event, it is historically unlikely.

With Super Tuesday defined, we move next to outlining the potential explanations of a candidate's performance in these events. To this point, presidential primary scholars focus primarily on explaining results from the Iowa caucuses, New Hampshire primaries, and the contested/aggregate primary vote (CPV and APV, respectively). These scholars use a variety of factors in an attempt to both explain and predict presidential primary outcomes. Steger (2007, 2008; 2013; 2015), Adkins and Dowdle (2002; 2001; 2005), Mayer (2000, 2003), and others (Cohen et al. 2008) model at least one of these dependent variables as a function of polling, media, endorsements, momentum, cash-on-hand, and/or public attention.

\section{Polling}

Haynes et al. (2004) identify three main resources of a presidential primary campaign: polling, press, and money. Polling is a direct measure of where a candidate stands in a given race. Although it is not a perfect predictor of who will win an election or nomination, candidates who poll better perform better. In this sense, polling is a standard explanatory variable when modeling presidential primary results because it is an indicator of support heading into an election (Mayer 2003, 1996b). Primary polling is important theoretically because it can signify which contests are divisive (Mayer 1996a). Similar to Haynes et al.'s (2004) model of candidate exits, strategic campaign decisions, such as how to deploy resources for Super Tuesdays, are at least partially informed by internal polls as they provide a measure of future success. Finally, while Steger (2007) finds that polling is significant only for Republican nomination battles, the general consensus among scholars is that polling helps predict nomination outcomes (Adkins and Dowdle 2001; Adkins and Dowdle 2005; Norrander 2006; Mayer 2003).

\section{Media}

The second of the resource triumvirate, media attention plays a critical role in presidential primary campaigns because it helps to tell voters what to think about (Steger 2015). Much of the media attention in presidential primaries focuses on the horse race and reflects a commercial bias, as the media will portray the races as exciting and/or controversial in an attempt to increase ratings (Norrander 2015, 96). There a couple of specific ways by which media attention impacts presidential primaries. First, candidates who receive a significant amount of 
media attention tend to stay in the race longer (Fei Shen 2008). Second, media attention can help long-shot candidates stay in a primary when they lag the frontrunners in other resources (Haynes et al. 2004; Haynes, Flowers, and Gurian 2002). Finally, media attention helps candidate performance in both Iowa and New Hampshire (Donovan and Hunsaker 2009). Since this literature finds a positive relationship between media attention and performance, we expect the same.

\section{Fundraising}

Fundraising is the last of the three main resources of a presidential campaign. As Hinckley and Green (1996) note, candidates must prioritize their fundraising organization in order to be successful. At the same time, it is very difficult to measure campaign organization, particularly in presidential primaries. Campaigns that last beyond the early states reshuffle their staffs according to financial resources and strategic decisions. None of these activities are reliably recorded. For instance, Feigenbaum and Shelton (2011) note that since FEC filings allow candidates to categorize spending, such reports are very broad and occur infrequently. Even if these reports were more specific and reliable, they would not allow us to measure the quality of an organization. Other conceptualizations of campaign organization, such as campaign field offices, are difficult to track during the middle to late stages of a presidential primary due to the compressed calendar. For these reasons, fundraising is frequently used as a proxy for campaign organization and/or activities (Curry, Herrnson, and Taylor 2013; Hinckley and Green 1996). While candidates can raise money based on their success in primary elections (Aldrich 1980), there is less certainty that raising money helps candidates win. While Adkins and Dowdle (2005; 2001) find that cash reserves can help scholars predict presidential primary outcomes, Steger (2007) finds that this only explains primary results for Democratic candidates. Still other scholars are unable to find evidence that money helps candidates win (Mayer 2003; Swearingen, Stiles, and Finneran 2019).

\section{Endorsements}

Endorsements are another important component of presidential primaries. Candidates seek the support of elected officials in an attempt to raise money and build a winning primary coalition (Cohen et al. 2008). Broadly speaking, endorsements help candidates increase their share of the primary vote (Steger 2008), although Steger (2015) argues that this only occurs when elites coalesce behind a particular candidate early in the process. For instance, while elite support played a role in the 2008 Democratic primaries (Summary 2010), Swearingen et al. (2019) find no evidence of elite influence in the 2016 GOP nomination. Since a higher share of endorsement signals greater cohesion of party elites behind a particular candidate, we expect a positive relationship between this factor and Super Tuesday performance.

\section{Momentum}


The logic of how momentum plays a role in presidential primaries is straightforward. A candidate wins and/or exceeds expectations in an early primary or caucus, which in turn leads to increased media attention and fundraising success. This combination of more media coverage and financial resources then translates into more votes (Steger 2008; Bartels 1988). While momentum is not the only way to win a presidential nomination, it helps explain candidate performance in the overall primary (Steger 2008), particularly in Democratic Party contests (Steger 2007). During the 2008 presidential primaries, both John McCain and Barack Obama were able to use their stances on the Iraq war into an early state victory and gain enough momentum to eventually secure their party's nomination (Norpoth and Perkins 2011). Still, there is some evidence suggesting that momentum may help candidates improve their relative standing among their competitors but not win the nomination (Adkins and Dowdle 2001). Recent primaries highlight the fleeting nature of momentum as Mike Huckabee (2008), Rick Santorum (2012), and Ted Cruz (2016) each won the first-in-the-nation Iowa caucuses but failed to win the GOP nomination. Among Democrats, Hillary Clinton (2008) and Bernie Sanders (2016) won New Hampshire but were unable to translate momentum into the nomination. In keeping with the literature, we expect a positive relationship between momentum and Super Tuesday performance.

\section{Public attention}

Public attention is a relative newcomer to the presidential primary literature and thusfar focuses on the invisible primary. Reuning and Dietrich (2016) find that public interest plays a key role in helping the media choose which candidates it covers. Similarly, Swearingen (2017) finds that increased public attention helps presidential candidates raise more money. Finally, public attention also helps explain which candidate wins the Iowa caucuses and New Hampshire primary as well as the contested primary vote (CPV, or a candidate's share of the vote while the presidential primary is actively contested) (Swearingen, Stiles, and Finneran 2019). These recent findings suggest that the mass public plays a significant role in deciding elections and we expect a similar relationship here.

\section{Data \& Methods}

In defining our cases, each primary election date with at least five actively contested primaries/caucuses was labeled as some sort of Super Tuesday by the media. Thus, we set this as the minimum number of states voting for one party's nomination at five. Across the 2004-2016 primary cycles, there were nine Super Tuesdays: February 3, 2004; March 2, 2004; February 5, 2008; March 6, 2012; April 12, 2012; March 1, 2016; March 15, 2016; April 26, 2016; and June 7, 2016. All told, this provided us with 429 candidate-election observations.

Since this manuscript builds on previous scholarships that explores who wins early nominating contests, we utilize similar statistical models. Our dependent variable is a candidate's share of a state's vote in a given primary or caucus on a Super Tuesday. This is calculated as the 
number of votes for a candidate divided by the sum of votes for all candidates still actively running at that time.

In our efforts to understand what contributes to a candidate's success on Super Tuesday, we include a number of explanatory variables. Many scholars discuss the role of elite endorsements in determining the outcome of a presidential primary (Cohen et al. 2008; Whitby 2014; Summary 2010; Steger 2007, 2015; Rapoport, Stone, and Abramowitz 1991). Similar to Swearingen, Stiles, and Finneran (2019), we measure a candidate's share of endorsement points at the time of a given Super Tuesday. Not all endorsements have an equal bearing (Cohen et al. 2008), we weight the endorsement points as follows: gubernatorial endorsements are worth 10 points; U.S. Senator endorsements are worth five points; U.S. Representative endorsements are worth one point. The main reason for our weights is that governors have more control over the state party as well as the distribution of funds throughout their state (Ansolabehere and Snyder 2006) than do U.S. Senators, especially those with greater control over the budgetary process (Barrilleaux and Berkman 2003, 409). We summed the total endorsement points for each candidate as of the Super Tuesday and divided it by the total endorsement points awarded on that day. For instance, heading into the March 2, 2004 Democratic Super Tuesday, John Kerry received 230 endorsement points out of a total of 305 awarded (or 75.41\%). Our source for the endorsement data for 2004, 2008, and 2012 is Democracy In Action; for 2016 it is fivethirtyeight.com. ${ }^{1}$

Media attention is measured as a candidate's share of local media stories within a state as reported by newlibrary.com, a news-aggregating website that includes not only newspaper stories but many local television stories as well. We searched each candidate's name in the database over the week prior to the Super Tuesday. To calculate the share of local media attention, we divided that candidate's mentions by the sum of all candidate mentions. We also looked at the media mentions for the two weeks preceding Super Tuesday, but a candidate's share did not change much as the correlation between the one-week and two-week measures was $0.99 .^{2}$

Analytically, including polling poses an interesting issue for our models. Not all polls are a valid measurement of where a race stands (Pickup and Johnston 2008) as polls can be inaccurate and/or biased (Martin, Traugott, and Kennedy 2005). Second, polling is often correlated with other measures of primary success such as media attention and public attention (e.g. Swearingen, Stiles, and Finneran, 2019). This reality is an important reason why additional public-driven measures, such as public attention, should be included in elections models. In this study, polling support is measured as a candidate's statewide share of the polls in the RealClearPolitics average

\footnotetext{
1 For more information, see the Democracy In Action endorsement sites for 2004, 2008, and 2012, and the fivethirtyeight.com endorsement tracker for 2016.

2 We also explored using national media attention using data from the Vanderbilt TV News Archive, again for the two weeks preceding Super Tuesdays. The national measures were highly correlated with local media attention ( $\mathrm{r}$ $=0.866$ for one week and $\mathrm{r}=0.874$ for two weeks).
} 
heading into Super Tuesday. However, there were multicollinearity issues when including both media attention and public attention in a model. ${ }^{3}$ We kept both variables in Model 3 in Table 1 so that readers can see their partial effects on the dependent variable. Because polling was not available for slightly over half of the observations, we drop polling in subsequent models.

Some recent studies look at the validity of using Google Trends as a measure of public attention (Ripberger 2011; Ellis, Ripberger, and Swearingen 2017), as well as its impact on election results (Swearingen, Stiles, and Finneran 2019; Reuning and Dietrich 2016). These studies indicate that, while not perfect, Google Trends effectively measures public attention and its relationship with political phenomena. We replicate their measures by calculating a candidate's share of public attention in a given state derived from Google Trends. ${ }^{4}$ This is done by entering each candidate's name into Google Trends for a party's candidate field in a particular state for the 90 days prior to the primary. The peak search traffic for a candidate during those 90 days is a 100; all other scores are relative to that point. Then we calculated each candidate's average share of the attention for the week heading into the primary For example, for the California primary on March 2, 2004, John Kerry's public attention score averaged 18.29, John Edwards' was 7.71, Dennis Kucinich's was 7.57, Howard Dean's was 4.71, and Al Sharpton's was 4.51. These scores total 42.85 , so dividing each candidate's score by that sum provides their share of public attention. We tried different weekly increments for public attention, ranging from one week to the full 90 days. Ultimately, the one-week measure since many exit polls indicates a strong plurality of voters decides who to vote for during the week leading up to the primary. Furthermore, a candidate's public attention share did not change much over the increments as the correlation between public attention share over the final week and final two weeks was 0.98 .

Next, similar to Adkins and Dowdle (2005) we include a candidate's share of the cashon-hand at the end of the month preceding a Super Tuesday. The data for this variable comes from the monthly FEC filing reports required of candidates once the primary phase of the nomination process begins. The percentage is calculated by taking a candidate's listed cash-onhand totals divided by the sum of all cash-on-hand totals for all candidates of that party still actively running at that time. Since much of the presidential primary focuses on momentum (Steger 2007; Norpoth and Perkins 2011; Fei Shen 2008; Donovan and Hunsaker 2009;

3 We use Gujarati's (2004) work as a reference on multicollinearity. We explored pair-wise correlations among the regressors, none of which were above 0.8 , a mark that could distinguish the presence of high collinearity. We also looked at each model's variance inflation factor (VIF); since media and public attention had VIFs of less than 10, we are confident there is not a high degree of multicollinearity due to the inclusion of these regressors. However, these tests indicated that there was evidence of multicollinearity between polling and media attention (for which, the VIF was 16.2).

4 See Ripberger (2011) and Swearingen and Ripberger (2014) for a more detailed look into the validity of Google Trends as a measure of public attention. 
Adkins and Dowdle 2001), we add a measure of the share of delegates won by each candidate heading into Super Tuesday. ${ }^{5}$

In addition to the explanatory variables, we included several controls. Because candidates in large primary fields can split the vote, we added a control for the number of candidates. We explored another control variable for the type of election (primary versus caucus), but it did not significantly add to the models. Finally, we include two candidate-driven dummy variables: one for if a Super Tuesday state bordered a candidate's home state and another if a candidate had a long-term personal history in that state. The latter was generally confined to a candidate's home state with the exceptions of Arkansas for Hillary Clinton and Utah for Mitt Romney. We limit this variable to direct personal experience because there is little evidence that candidates receive a regional bounce (Norrander 1992).

Because the public attention variable is available starting in 2004, we look at all Super Tuesday states beginning with that cycle. This yields a total of 429 observations (each candidate by state), 211 of which had an RCP polling average while 218 did not. Since we have multiple candidates in a single-state election, we use fixed effects regression accounting for both factors using the "plm" package in R 3.5.1. Due to the presence of heteroscedasticity, we report robust standard errors.

\section{Results \& Discussion}

We run three main models of a candidate's share of the vote in a Super Tuesday state where polling was available. Due to the presence of multicollinearity between polling and media attention, we ran one model without one of the two offending variables and a third that included both. Each model has an adjusted R-square of at least 0.61 and a statistically significant Fstatistic.

Although Model 1 leaves out the polling variable, there are still a couple of interesting findings. First, public attention is statistically and substantively significant in explaining a candidate's Super Tuesday performance. For each one percent increase in a candidate's share of public attention, their share of the vote is expected to increase by 0.79 points. This means that a candidate one standard deviation above the mean is expected to receive nearly 39 percent more of the vote than the average candidate.

The substantive importance of public attention helps us understand the success of some presidential primary candidates. Barack Obama's candidacy was greatly aided by the amount of public attention he received. Heading into the February 5, 2008 Super Tuesday, he regularly received over 60 percent of the public attention compared to his chief rival, Hillary Clinton. While polling indicated he trailed Senator Clinton in Alabama and Missouri, he ended up

\footnotetext{
${ }^{5}$ We also looked at the percentage of states won, total states won, total caucuses won, and whether the candidate won the Iowa caucuses and/or New Hampshire primary. Because the nomination process is about winning delegates, we settled on this measure of momentum.
} 
winning those states. The same held for Donald Trump's campaign in the 2016 GOP primary. In a field of five candidates heading into the March 1 Super Tuesday, he dominated in public attention, garnering well over 60 percent in many of the states. This helped him pull out a narrow victory over Florida Senator Marco Rubio in Virginia and win easily in southern states targeted by Ted Cruz, such as Alabama and Georgia.

The second interesting finding from Model 1 is that the substantive impact of local media attention is higher than that of public attention. A one percent increase in local media attention is expected to bring an additional 1.13 percent of support in a Super Tuesday state. Greater media attention surrounding front-running candidates certainly helps them solidify their status, but it can also help less-known candidates in the right circumstances. On the February 5, 2008 GOP Super Tuesday, Ron Paul (TX) averaged roughly 7.5 percent of the vote across the twenty primaries/caucuses. In the three caucus states where his local media share was over 20 percent - Alaska, Minnesota, and Montana - he averaged over 19 percent of the vote.

When polling is not included, a candidate is expected to receive a nearly nine percent bump in performance in states where they have a strong personal history. This same cannot be said for neighboring states, which fails to reach statistical significance. Also worth noting is that Model 1 is the only one for which a candidate's share of cash-on-hand is significant. Rather than helping a candidate, though, this variable is expected to decrease their performance.

The next model replaces media attention with polling; while the adjusted R-square remains the same, the F-statistic jumps from 45.16 to 131.22 . The key finding in this model is that the public-driven measures are the key drivers of candidate performance. With a coefficient of 0.91, polling is strongly significant; in Model 3, which includes media attention, the coefficient only drops slightly (0.80). This indicates that despite some highly publicized misses in predicting Super Tuesday outcomes, polling is still a starting point when discussing electoral performance.

Public attention is significant even when controlling for polling and, in Model 3, media attention. The coefficient for both models is between 0.47 and 0.41 , indicating substantive significance as well. The average candidate is expected to add $11.6-13.3$ percent to their performance; above-average candidates (one standard deviation) are expected to add $20.2-23.2$ percent. Again, this underscores the importance of public-driven measures in explaining electoral performance.

There are two changes in Model 2 compared to Model 1. First, candidates are not expected to increase their vote share in personal states, likely due to the inclusion of polling in the model. This finding holds for Model 3 as well. Candidates are, however, are expected to receive a two percent increase in neighboring states, mirroring other scholars (Norrander 1993) that found geography plays a role in Super Tuesday results. Second, once polling is added to the model, cash-on-hand ceases to achieve statistical significance. This could be due to the post-Iowa and New Hampshire that winnows out weaker candidates from the race (Norrander 2006); by the time Super Tuesday arrives, many of the remaining candidates have some fundraising ability. 
American Review of Politics

Volume 37 No. 2

Table 1. Models of Polled Super Tuesday States, 2004 - 2016

\begin{tabular}{|c|c|c|c|}
\hline & Model 1 & Model 2 & Model 3 \\
\hline \multicolumn{4}{|l|}{ Elite-Driven Measures } \\
\hline Endorsements (Pct) & $\begin{array}{l}-0.02 \\
(0.05)\end{array}$ & $\begin{array}{c}0.05 \\
(0.48)\end{array}$ & $\begin{array}{c}0.02 \\
(0.05)\end{array}$ \\
\hline $\begin{array}{r}\text { Local Media Attention } \\
\text { (Pct) }\end{array}$ & $\begin{array}{l}1.13^{* * *} \\
(0.14)\end{array}$ & ---- & $\begin{array}{l}0.43^{* *} \\
(0.14)\end{array}$ \\
\hline
\end{tabular}

Public-Driven Measures

\begin{tabular}{|c|c|c|c|}
\hline Public Attention (Pct) & $\begin{array}{l}0.79^{* * *} \\
(0.13)\end{array}$ & $\begin{array}{c}0.47^{* * *} \\
(0.10)\end{array}$ & $\begin{array}{l}0.41^{* * *} \\
(0.10)\end{array}$ \\
\hline Poll Standing & ----- & $\begin{array}{c}0.91^{* * *} \\
(0.04)\end{array}$ & $\begin{array}{c}0.80^{* * *} \\
(0.04)\end{array}$ \\
\hline \multicolumn{4}{|l|}{ Candidate-Driven Measures } \\
\hline Personal State & $\begin{array}{l}8.58^{* * *} \\
(2.12)\end{array}$ & $\begin{array}{c}1.59 \\
(1.42)\end{array}$ & $\begin{array}{c}0.58 \\
(1.42)\end{array}$ \\
\hline Neighbor State & $\begin{array}{c}3.05 \\
(2.66)\end{array}$ & $\begin{array}{l}2.03^{*} \\
(0.89)\end{array}$ & $\begin{array}{c}1.85^{*} \\
(0.89)\end{array}$ \\
\hline \multicolumn{4}{|l|}{ Fundraising Measures } \\
\hline Cash-on-Hand (Pct) & $\begin{array}{c}-0.49^{* * *} \\
(0.11)\end{array}$ & $\begin{array}{c}0.09 \\
(0.17)\end{array}$ & $\begin{array}{l}-0.05 \\
(0.13)\end{array}$ \\
\hline \multicolumn{4}{|l|}{ Momentum Measures } \\
\hline Share of Delegates Won & $\begin{array}{l}0.27^{*} \\
(0.12)\end{array}$ & $\begin{array}{l}-0.09 \\
(0.13)\end{array}$ & $\begin{array}{l}-0.03 \\
(0.10)\end{array}$ \\
\hline \multicolumn{4}{|l|}{ Other } \\
\hline Number of Candidates & $\begin{array}{c}1.19 \\
(1.54)\end{array}$ & $\begin{array}{c}1.00 \\
(0.91)\end{array}$ & $\begin{array}{l}1.38^{* *} \\
(0.52)\end{array}$ \\
\hline Adj. $R^{2}$ & 0.61 & 0.83 & 0.85 \\
\hline F-Statistic & $45.16^{* * *}$ & $131.22^{* * *}$ & $132.7^{* * *}$ \\
\hline$N$ & 211 & 211 & 211 \\
\hline \multicolumn{4}{|c|}{$\begin{array}{l}\text { Dependent variable is a candidate's vote share. Fixed effects regression model with robust standard errors in } \\
\text { parentheses. One-tail test where hypothesized. } \\
{ }^{*} p<0.05 ;{ }^{* *} p<0.01 ;{ }^{* *} p<0.001\end{array}$} \\
\hline
\end{tabular}

Finally, Model 3 adds local media attention back into the analysis. Despite the multicollinearity between polling and media attention, there are no changes to the substantive or statistical significance of public attention, polling, or the neighbor state bump. With a coefficient of 0.43 , the media attention variable is an important driver of Super Tuesday performance. The typical candidate is expected to receive an additional 12 percent from media attention, while above-average candidates (by one standard deviation) are expected to get an almost 19 percent increase. The stability of this model suggests that all three consistently significant variables play a role in understanding Super Tuesday performance. 
Polling is available for roughly half (211 of 429) cases in our data set. In order to understand who wins Super Tuesday races where there is no polling data, we ran two models that removed polling - one for all 429 observations and another for the 218 cases where polling did not exist (Table 2). These models perform well with adjusted R-squares of 0.51 and 0.42 , respectively, and statistically significant F-statistics ( $p<0.001$ for both).

Table 2: Non-Polling-Based Models of Super Tuesday Results, $2004-2016$

\begin{tabular}{|c|c|c|}
\hline & All Cases & Polls Unavailable \\
\hline \multicolumn{3}{|l|}{ Elite-Driven Measures } \\
\hline Endorsements (Pct) & $\begin{array}{c}0.13^{* * *} \\
(0.04)\end{array}$ & $\begin{array}{c}0.17^{* * *} \\
(0.04)\end{array}$ \\
\hline Local Media Attention (Pct) & $\begin{array}{l}1.15^{* * *} \\
(0.11)\end{array}$ & $\begin{array}{l}1.09^{* * *} \\
(0.13)\end{array}$ \\
\hline \multicolumn{3}{|l|}{ Public-Driven Measures } \\
\hline Public Attention (Pct) & $\begin{array}{c}0.53^{* * *} \\
(0.14)\end{array}$ & $\begin{array}{l}0.42^{* *} \\
(0.14)\end{array}$ \\
\hline \multicolumn{3}{|l|}{ Candidate-Driven Measures } \\
\hline Personal State & $\begin{array}{c}12.69^{* * *} \\
(1.95)\end{array}$ & $\begin{array}{c}20.18^{* * *} \\
(2.91)\end{array}$ \\
\hline Neighbor State & $\begin{array}{l}2.85^{*} \\
(1.32)\end{array}$ & $\begin{array}{c}0.98 \\
(2.09)\end{array}$ \\
\hline \multicolumn{3}{|l|}{ Fundraising Measures } \\
\hline Cash-on-Hand (Pct) & $\begin{array}{c}-0.59^{* * *} \\
(0.15)\end{array}$ & $\begin{array}{l}-0.52^{*} \\
(0.22)\end{array}$ \\
\hline \multicolumn{3}{|l|}{ Momentum Measures } \\
\hline Share of Delegates Won & $\begin{array}{c}0.08 \\
(0.15)\end{array}$ & $\begin{array}{l}-0.09 \\
(0.17)\end{array}$ \\
\hline \multicolumn{3}{|l|}{ Other } \\
\hline Number of Candidates & $\begin{array}{c}1.31 \\
(1.02)\end{array}$ & $\begin{array}{c}1.64 \\
(1.38)\end{array}$ \\
\hline Adj. $R^{2}$ & 0.51 & 0.42 \\
\hline F-Statistic & $59.34^{* * *}$ & $23.87^{* * *}$ \\
\hline$N$ & 429 & 218 \\
\hline \multicolumn{3}{|c|}{$\begin{array}{l}\text { Dependent variable is a candidate's vote share. Fixed effects regression model with robust standard errors ir } \\
\text { parentheses. One-tailed test where hypothesized. } \\
{ }^{*} p<0.05 ;{ }^{* *} p<0.01 ;{ }^{* *} p<0.001\end{array}$} \\
\hline
\end{tabular}


Looking at both models, public attention again plays a key role in improving candidate performance in Super Tuesday contests. With a coefficient of 0.53 , candidates with aboveaverage public attention are expected to receive an additional 26 percent of the vote. Among the cases without a polling average, this coefficient drops slightly but is still expected to add 21 percent to a candidate with above-average public attention. Taken jointly, these results reiterate that public attention is an important metric with which to measure campaign effectiveness.

Media attention is another factor that helps explain Super Tuesday performance. In fact, sans polling, an additional one percent in local media attention vis-à-vis the opposition is expected to add just over one percent to a candidate's vote total. This underscores the importance of campaign stops and interviews with local media outlets. Beyond the early primary/caucus states when candidates can attack each race singly, a campaign must make strategic decisions about where to go. As Bartels (1985) notes, the candidate is a campaign's greatest resource, in part because of the media attention that follows him/her. Generating greater media attention is not only a sound strategy, it serves as a barometer of who may be performing well in a given state.

Importantly, Table 2 shows that in some cases, elite endorsements can help explain Super Tuesday results. For all cases, a one-percent increase in endorsements is expected to add 0.13 percent to a candidate's vote share; for cases where polling is unavailable, the coefficient is 0.17 . This indicates that candidates who are able to win an above-average backing of key party elites can add between seven and nine percent to their vote share in a Super Tuesday state. This finding reiterates Steger's (2015) notion that when the establishment is unified, that candidate has a much higher chance of performing well in presidential primaries.

Without polling included in the models, the variable for a candidate's personal state is again significant. In all observations, a candidate is expected to increase their vote share a bit less than 13 percent in personal states; in states without polling available, the impact increase to over 20 percent. Finally, cash-on-hand is a statistically significant, negative determinant of Super Tuesday performance. Again, this could be due to the quality of candidates remaining beyond the initial primary/caucus states.

The no polling models are robust in explaining Super Tuesday results when combining observations from all four election cycles. Does this hold when analyzing each cycle independently? It is plausible that there were cycle-specific anomalies that get covered up by the overall sample. For instance, did Howard Dean's highly-covered scream on the night of the 2004 Iowa caucuses increase his share of both media and public attention, even though he averaged less than ten percent of the vote in the February 3 Super Tuesday? We note the RCP polling average is not included for two reasons. First, there was a problem with multicollinearity for the 2012 races between polling and local media attention. Second, there were relatively few observations with polling data in 2004 and 2012, the years when only one party had a contested presidential primary. In order to make comparisons across election cycles, we decided to drop the polling variable. 
Table 3: Regression Models of Super Tuesday Results, by Cycle

\begin{tabular}{|c|c|c|c|c|}
\hline & 2004 & 2008 & 2012 & 2016 \\
\hline \multicolumn{5}{|l|}{ Elite-Driven Measures } \\
\hline Endorsements (Pct) & $\begin{array}{c}0.16 \\
(0.09)\end{array}$ & $\begin{array}{l}-0.10 \\
(0.14)\end{array}$ & $\begin{array}{l}-0.56 \\
(0.41)\end{array}$ & $\begin{array}{l}0.11^{* *} \\
(0.04)\end{array}$ \\
\hline Local Media Attention (Pct) & $\begin{array}{l}1.13^{* * *} \\
(0.29)\end{array}$ & $\begin{array}{c}0.84^{* * *} \\
(0.14)\end{array}$ & $\begin{array}{l}1.10^{* *} \\
(0.32)\end{array}$ & $\begin{array}{l}0.59^{* * *} \\
(0.12)\end{array}$ \\
\hline \multicolumn{5}{|l|}{ Public-Driven Measures } \\
\hline Public Attention (Pct) & $\begin{array}{c}0.06 \\
(0.05)\end{array}$ & $\begin{array}{l}1.19^{* * *} \\
(0.13)\end{array}$ & $\begin{array}{l}0.54^{* * *} \\
(0.08)\end{array}$ & $\begin{array}{l}1.14^{* * *} \\
(0.11)\end{array}$ \\
\hline \multicolumn{5}{|l|}{ Candidate-Driven Measures } \\
\hline Personal State & $\begin{array}{l}14.40^{*} \\
(5.63)\end{array}$ & $\begin{array}{c}9.55^{* * *} \\
(1.87)\end{array}$ & $\begin{array}{c}17.80^{* * *} \\
(2.55)\end{array}$ & $\begin{array}{c}12.26^{* * *} \\
(3.29)\end{array}$ \\
\hline Neighbor State & $\begin{array}{c}2.94 \\
(2.94)\end{array}$ & $\begin{array}{c}3.50 \\
(1.94)\end{array}$ & $\begin{array}{l}3.02^{*} \\
(1.50)\end{array}$ & $\begin{array}{c}0.86 \\
(1.88)\end{array}$ \\
\hline \multicolumn{5}{|l|}{ Fundraising Measures } \\
\hline Cash-on-Hand (Pct) & $\begin{array}{c}-0.58^{* *} \\
(0.19)\end{array}$ & ---- & $\begin{array}{c}0.51 \\
(0.37)\end{array}$ & $\begin{array}{c}-1.02^{* * *} \\
(0.14)\end{array}$ \\
\hline \multicolumn{5}{|l|}{ Momentum Measures } \\
\hline Share of Delegates Won & $\begin{array}{c}0.10 \\
(0.15)\end{array}$ & ---- & $\begin{array}{l}-0.05 \\
(0.09)\end{array}$ & $\begin{array}{c}0.44^{* * *} \\
(0.10)\end{array}$ \\
\hline \multicolumn{5}{|l|}{ Other } \\
\hline Number of Candidates & $\begin{array}{c}1.49 \\
(0.89)\end{array}$ & ---- & ---- & $\begin{array}{l}-4.08 \\
(2.71)\end{array}$ \\
\hline Adj. $R^{2}$ & 0.42 & 0.64 & 0.66 & 0.53 \\
\hline F-Statistic & $10.68^{* * *}$ & $47.56^{* * *}$ & $17.08^{* * *}$ & $22.22^{* * *}$ \\
\hline$N$ & 99 & 128 & 58 & 144 \\
\hline \multicolumn{5}{|c|}{$\begin{array}{l}\text { Dependent variable is a candidate's vote share. Fixed effects regression model with robust standard errors in } \\
\text { parentheses. One-tailed test where hypothesized. } \\
{ }^{*} p<0.05 ;{ }^{* *} p<0.01 ;{ }^{* * *} p<0.001\end{array}$} \\
\hline
\end{tabular}

As Table 3 indicates, the no polling model holds up fairly well when disaggregating the cases by election cycle. Local media attention is a driving factor of Super Tuesday performance, as is having a personal history in a state. There are some differences across the cycles when it comes to public attention, which is significant in each cycle except 2004. This is where we see some evidence that the "Dean Scream" may have inflated Howard Dean's share of the public attention. In the states voting on February 3, Dean averaged 9.96 percent of the vote (fourth place among Democratic candidates) but over 20 percent of the public attention share (second highest). One month later, Dean averaged 8.7 percent of the vote, third-highest behind John Kerry and John Edwards; by this time, he had dropped to third place in public attention. In 2008, 
public attention was significant, adding an expected 1.19 percent of the vote for each one percent increase in attention. On the Democratic side, Barack Obama received over 57 percent of the local media attention heading into Super Tuesday and almost 70 percent of the public attention en route to winning 13 of the 22 states. Among Republicans, John McCain received about 41 percent of the public attention and 34 percent of the local media attention as he won the plurality of Super Tuesday contests. ${ }^{6}$

Four years later, local media attention was once again the strongest predictor of Super Tuesday results. This could be due to Ron Paul averaging 34 percent of the public attention but only 16 percent of the vote across 14 states and two Super Tuesdays. Still, public attention was significant, and each one percentage increase was expected to add about 0.5 points to a candidate's vote share. In 2016, public attention had a higher coefficient, perhaps in part to the dominance of Bernie Sanders and Donald Trump in getting people to pay attention to their campaigns. Interestingly, 2016 was the only year for which endorsements were an asset - each increase in a candidate's endorsement share was expected to add 0.11 percent of the vote on Super Tuesday. For above-average candidates, this meant an added six percent of the vote. Again, these models reiterate the strength of both local media attention and public attention as key predictors of Super Tuesday results, particularly in the absence of polling data.

Table 4: Regression Models of Super Tuesday Results, by Party

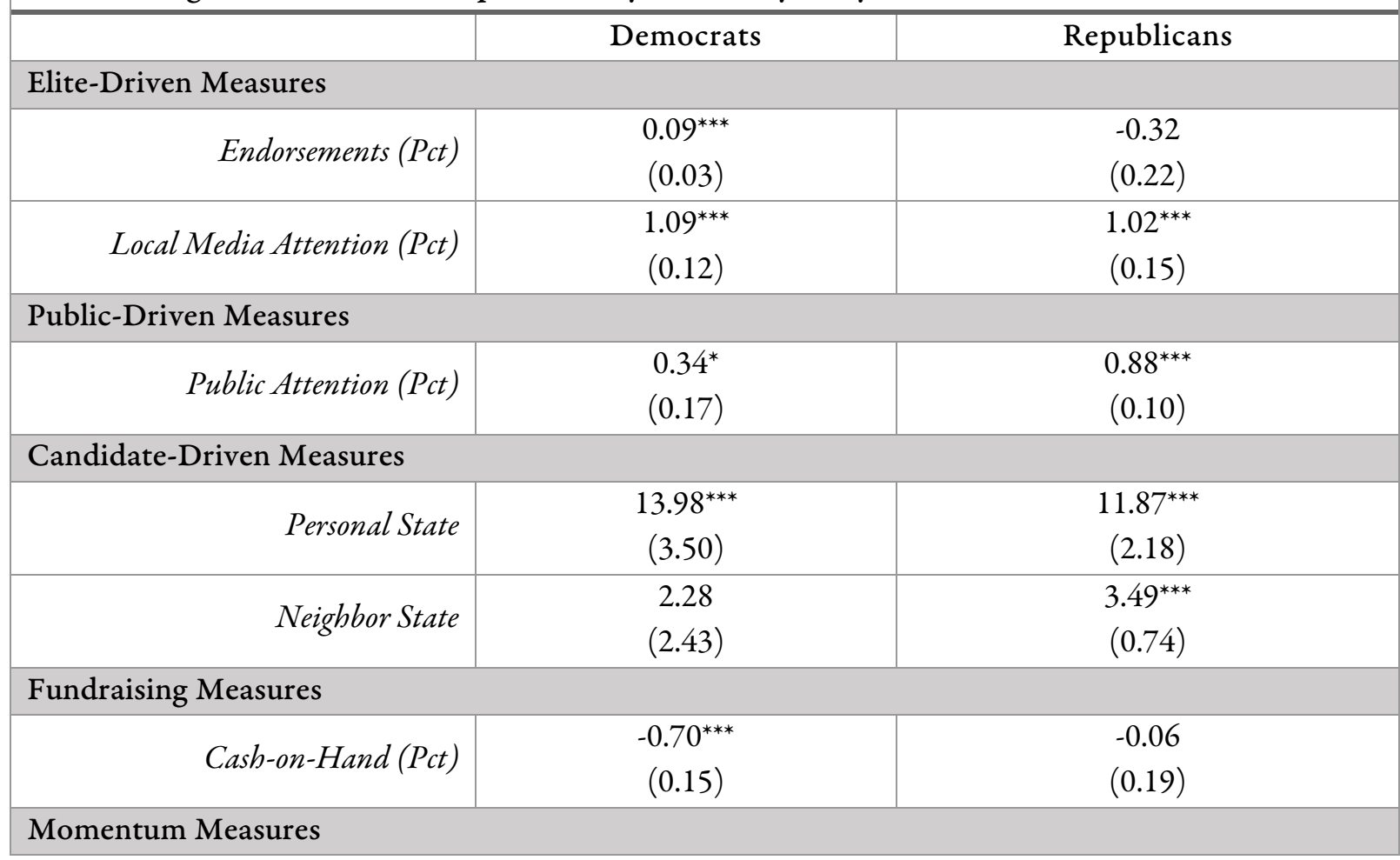

\footnotetext{
${ }^{6}$ Because there was only one Super Tuesday in 2008 and our models control for candidate and state fixed-effects, the cash-on-hand, share of prior delegates won, and number of candidates variables did not vary along these clusters and were thus removed from the model.
} 


\begin{tabular}{|c|c|c|}
\hline Share of Delegates Won & $\begin{array}{c}0.16 \\
(0.15)\end{array}$ & $\begin{array}{c}0.13 \\
(0.11)\end{array}$ \\
\hline \multicolumn{3}{|l|}{ Other } \\
\hline Number of Candidates & $\begin{array}{c}1.42^{*} \\
(0.68)\end{array}$ & $\begin{array}{c}0.32 \\
(1.65)\end{array}$ \\
\hline Adj. $\mathrm{R}^{2}$ & 0.37 & 0.66 \\
\hline F-Statistic & $15.07^{* * *}$ & $51.55^{* * *}$ \\
\hline$N$ & 197 & 232 \\
\hline
\end{tabular}

Finally, because Republicans and Democrats vary in their delegate distribution rules, we ran the models for each party (Table 4 ). There are some similarities across political party. Local media attention is a statistically significant factor in explaining Super Tuesday vote share $(b=$ 1.09 for Democrats and 1.02 for Republicans) and having a primary/caucus in a home state can add around 12-14 percent to a candidate's total. While public attention is statistically significant for both parties, there is a substantive difference. For Democrats, a one-percent increase in public attention was expected to add 0.34 percent to a candidate's vote share, compared to 0.88 percent for Republicans.

Interestingly, there were some differences across party. Endorsements were statistically significant for Democrats, but not for Republicans. A one-percent increase in endorsements was expected to add 0.09 percent to a Democrat's vote share. The same was true for both cash-onhand and the number of candidates still in the race. Counterintuitively, cash-on-hand was a negative predictor of Super Tuesday performance, while the number of candidates was positive. One possible explanation for the latter is that with more candidates in the race, voters were more concerned with viability. With respect to the former, we admit to being puzzled by this result. A simple mean comparison indicates that the average vote share is inversely related to the number of candidates in the race. Perhaps this finding is due to the winnowing process of presidential primaries: those candidates running come Super Tuesday may have more resources and a better ground game which may help the median candidate, although not the mathematically average one. For instance, in reviewing the descriptive statistics, we found that median vote share increased as the field moved from six to seven candidates and the median vote share at three and four candidates was very similar. Still, this finding is not consistent across all our models and we hesitate to read too much into it.

\section{Conclusion}

In this study, we explore which factors help explain the outcome of Super Tuesday races. While polling is a main determinant of Super Tuesday performance, it is not the only one. Both public attention and media attention are consistently statistically and substantively significant, particularly when polling data are not available for a state. The strong findings for polling, public 
attention, and media attention indicate that elections are more complex than simply stating that the polling frontrunner will win a given state. These complexities are highlighted by the lack of polling in many Super Tuesday caucus states. Because of this, pundits and scholars need to examine additional data to understand and predict Super Tuesday races. Both public attention and media attention are important indices to explore in this context. Even when polling data are available, the industry has been hit with questions of its validity after some recent high-profile misses (Zukin 2015; Silver 2014). Comparing polling results to other data can help scholars and pundits make better predictions and understand when polling could be wrong.

One interesting component of our results is that, while there is explanatory overlap between Super Tuesday and early nomination contests, there are some key differences. In terms of Haynes et al.'s (2004) resource triumvirate, polling and media attention matter while cash-onhand does not. Moreover, we find that upstart candidates can use local media and public attention to win states even if they are at a financial disadvantage. Those who are able to create considerable interest among primary voters were consistently able to outperform their challengers. This finding is more optimistic for such candidates than previous studies of presidential primary results. Future research should explore how candidates can create positive public attention moments for their campaign and how the timing of such moments could affect the primary process.

Also worth noting is that candidates receive a bit of a boost in geographically proximal states (Norrander 1993). The results are more mixed when considering states where candidates have a personal history, however. This variable is only significant when polling data are unavailable or not included in a model. This does not mean that candidates do not benefit from having their state host a Super Tuesday election. Indeed, only four candidates lost their home state in this sample: Dennis Kucinich and Al Sharpton in 2008, Rick Santorum in 2012, and Marco Rubio in 2016. The first two candidates were unlikely to win because they were not strong contenders for the nomination. The last two cases are a bit more interesting. Santorum lost his home state of Pennsylvania to Mitt Romney, 58 percent to 18 percent, at the end of April. By this time in the primary, Romney had won 24 states to Santorum's 10; Romney had won almost 62 percent of the prior delegates. In other words, Romney was the presumptive nominee fending off the last-ditch efforts of his opposition. Rubio's loss at the hands of Donald Trump came earlier in the primary process, six weeks after the Iowa caucuses, and represented the end of his campaign. Rubio had won Minnesota and Washington, DC, prior to the March 15 Super Tuesday, but Trump entered the day with wins in 15 states and was beginning to receive stronger backing from GOP primary voters. While other Republicans continued to challenge Trump for more than a month after March 15, his status as frontrunner was not in doubt.

The final noteworthy observation from this study is that cash-on-hand and endorsements do not consistently help candidates win Super Tuesday races. The null finding for financial resources underscores the fiscal reality of Super Tuesdays: in order to compete in at least five elections on one day requires a certain fundraising competence. This reiterates the finding 
from other scholars that fundraising is a necessary but insufficient condition for presidential primary success (Goff 2004; Adkins and Dowdle 2002; Mayer 2003). This can be seen from a deeper dive into the data; in most election cycles, the candidates competing in Super Tuesdays were all relatively proficient fundraisers. Among Democrats, every Super Tuesday in 2008 and 2016 was contested by only two candidates - Barack Obama and Hillary Clinton in 2008, and Hillary Clinton and Bernie Sanders in 2016. Among Republicans, there were more candidates, but almost all of them had money. Those candidates that lacked resources were still able to win some states, including Donald Trump, who had less than 10 percent of the field's cash-on-hand in the first two 2016 Super Tuesdays.

Based on these results, there are numerous avenues for future research on Super Tuesday elections. First, polling, public attention, and media attention are interrelated. Candidates who do well in one area typically do well in the other two. The nature of these relationships could be explored in more depth, perhaps using case studies or a time-series analysis. Second, underfunded candidates can eke out victories in demographically and socio-economically favorable states. For example, Rick Santorum, despite winning the 2012 Iowa caucuses, was less organized than Mitt Romney. Still, he was able to win numerous Super Tuesday states, such as North Dakota, Oklahoma, and Tennessee. Which demographic and socio-economic factors made these states prime targets for his campaign? By exploring these questions, scholars can better understand the nuances of presidential primaries and how we elect our chief executive.

Finally, more work needs to be done to explore how campaigns strategically attempt to influence Super Tuesday voters. Wendland's (2017) recent book on campaign visits and presidential primaries is an important guide here. He notes that visits play a prominent role in campaign strategy and can make a positive difference for some candidates. Combining visits with survey data from Super Tuesday voters may help scholars better understand campaign effects in the presidential primary process. 


\section{Bibliography}

Abramson, Paul R., John H. Aldrich, Phil Paolino, and David W. Rohde. 1992. “'Sophisticated' Voting in the 1988 Presidential Primaries." The American Political Science Review 86 (1): 55. https://doi.org/10.2307/1964015.

Adkins, R. E., and A. J. Dowdle. 2001. "How Important Are Iowa and New Hampshire to Winning Post-Reform Presidential Nominations?” Political Research Quarterly 54 (2): 431-44. https://doi.org/10.1177/106591290105400210.

Adkins, Randall E., and Andrew J. Dowdle. 2005. "Do Early Birds Get the Worm? Improving Timeliness of Presidential Nomination Forecasts." Presidential Studies Quarterly 35 (4): 646-60. https://doi.org/10.1111/j.1741-5705.2005.00270.x.

Adkins, Randall E., and Andrews J. Dowdle. 2002. “The Money Primary: What Influences the Outcome of Pre-Primary Presidential Nomination Fundraising?” Presidential Studies Quarterly 32 (2): 256-75. https://doi.org/10.1111/j.0360-4918.2002.00220.x.

Aldrich, John Herbert. 1980. Before the Convention: Strategies and Choices in Presidential Nomination Campaigns. Chicago: University of Chicago Press.

Ansolabehere, Stephen, and James M. Snyder. 2006. "Party Control of State Government and the Distribution of Public Expenditures*." The Scandinavian Journal of Economics 108 (4): 547-69. https://doi.org/10.1111/j.1467-9442.2006.00470.x.

Barrilleaux, Charles, and Michael Berkman. 2003. "Do Governors Matter? Budgeting Rules and the Politics of State Policymaking." Political Research Quarterly 56 (4): 409-17. https://doi.org/10.2307/3219802.

Bartels, Larry M. 1985. “Resource Allocation In a Presidential Campaign.” The Journal of Politics 47 (3): 928-36. https://doi.org/10.2307/2131218.

Bartels, Larry M.. 1988. Presidential Primaries and the Dynamics of Public Choice. Princeton, N.J: Princeton University Press.

Bartels, Larry M.. 1989. “After Iowa: Momentum in Presidential Primaries.” In The Iowa Caucuses and the Presidential Nominating Process, 121-48. Boulder: Westview Press. 
Bartels, Larry M.. 1993. "Messages Received: The Political Impact of Media Exposure.” American Political Science Review 87 (02): 267-85. https://doi.org/10.2307/2939040.

Bradner, Eric. 2016. "Your Guide to Super Tuesday 3.” CNN, March 15, 2016. http://www.cnn.com/2016/03/14/politics/super-tuesday-march-15-guide-floridaillinois-ohio/.

Church, George. 1984. “A Big Bicoastal Finale.” Time, June 4, 1984. http://content.time.com/time/magazine/article/0,9171,951132-1,00.html.

Cohen, Marty, David Karol, Hans Noel, and John Zaller. 2008. The Party Decides: Presidential Nominations before and after Reform. Chicago Studies in American Politics. Chicago: University of Chicago Press.

Collinson, Stephen. 2016. “Trump, Clinton Score Major Victories.” CNN, April 27, 2016. http://www.cnn.com/2016/04/26/politics/primary-results-highlights/.

Curry, James M., Paul S. Herrnson, and Jeffrey A. Taylor. 2013. "The Impact of District Magnitude on Campaign Fundraising: Campaign Fundraising." Legislative Studies Quarterly 38 (4): 517-43. https://doi.org/10.1111/1sq.12026.

Donovan, Todd, and Rob Hunsaker. 2009. "Beyond Expectations: Effects of Early Elections in U.S. Presidential Nomination Contests.” PS: Political Science \& Politics 42 (01): 45. https://doi.org/10.1017/S1049096509090040.

Ellis, William Curtis, Joseph T. Ripberger, and C. Douglas Swearingen. 2017. "Public Attention and Head-to-Head Campaign Fundraising: An Examination of U.S. Senate Elections." American Review of Politics 36 (1): 30-53.

Fei Shen. 2008. "Staying Alive: The Impact of Media Momentum on Candidacy Attrition in the 1980--2004 Primaries." The International Journal of Press/Politics 13 (4): 429-50. https://doi.org/10.1177/1940161208323550.

Feigenbaum, James J., and Cameron A. Shelton. 2011. "The Vicious Cycle: Fundraising and Perceived Viability in US Presidential Primaries." Quarterly Journal of Political Science 6 (2): 137-78. https://doi.org/10.1561/100.00011094. 
Goff, Michael J. 2004. The Money Primary: The New Politics of the Early Presidential Nomination Process. Lanham, MD: Rowman \& Littlefield Publishers.

Gurian, Paul-Henri. 1993. “The Distribution of News Coverage in Presidential Primaries.” Journalism Quarterly 70 (2): 336-44.

Hadley, Charles D., and Harold W. Stanley. 1989. "Super Tuesday 1988: Regional Results and National Implications." Publius 19 (3): 19-37.

Haynes, A. A., J. F. Flowers, and P.-H. Gurian. 2002. “Getting the Message Out: Candidate Communication Strategy During the Invisible Primary." Political Research Quarterly 55 (3): 633-52. https://doi.org/10.1177/106591290205500307.

Haynes, Audrey A., Paul-Henri Gurian, Michael H. Crespin, and Christopher Zorn. 2004. "The Calculus of Concession: Media Coverage and the Dynamics of Winnowing in Presidential Nominations." American Politics Research 32 (3):310-37. https://doi.org/10.1177/1532673X03260353.

Hinckley, K. A., and J. C. Green. 1996. "Fund-Raising in Presidential Nomination Campaigns: The Primary Lessons of 1988." Political Research Quarterly 49 (4): 693-718. https://doi.org/10.1177/106591299604900401.

Kenney, Patrick J., and Tom W. Rice. 1984. "The Effect of Primary Divisiveness in Gubernatorial and Senatorial Elections.” The Journal of Politics 46 (3): 904-15. https://doi.org/10.2307/2130861.

Martin, E. A., Michael W. Traugott, and Courtney Kennedy. 2005. "A Review and Proposal for a New Measure of Poll Accuracy." Public Opinion Quarterly 69 (3): 342-69. https://doi.org/10.1093/poq/nfi044.

Mayer, William G. 1996a. “Forecasting Nominations.” In In Pursuit of the White House: How We Choose Our Presidential Nominees, 44-71. Chatham, NJ: Chatham House Publishers.

Mayer, William G. 1996b. "Comment: Of Money and Momentum.” Political Research Quarterly 49 (4): 719-26. https://doi.org/10.1177/106591299604900402. 
Mayer, William G. ed. 2000. In Pursuit of the White House 2000: How We Choose Our Presidential Nominees. New York: Chatham House Publishers.

Mayer, William G. 2003. "Forecasting Presidential Nominations or, My Model Worked Just Fine, Thank You." Political Science and Politics 36 (02): 153-57. https://doi.org/10.1017/S1049096503001999.

Mayer, William G., and Andrew Busch. 2004. The Front-Loading Problem in Presidential Nominations. Washington, D.C: Brookings Institution Press.

Norpoth, Helmut, and David F. Perkins. 2011. "War and Momentum: The 2008 Presidential Nominations." PS: Political Science \& Politics 44 (03): 536-43. https://doi.org/10.1017/S1049096511000631.

Norrander, Barbara. 1992. Super Tuesday: Regional Politics \& Presidential Primaries. Lexington, Ky: University Press of Kentucky.

Norrander, Barbara. 1993. "Nomination Choices: Caucus and Primary Outcomes, 1976-88." American Journal of Political Science 37 (2): 343. https://doi.org/10.2307/2111376.

Norrander, Barbara.2000. “The End Game in Post-Reform Presidential Nominations.” The Journal of Politics 62 (04). https://doi.org/10.1111/0022-3816.00043.

Norrander, Barbara. 2006. “The Attrition Game: Initial Resources, Initial Contests and the Exit of Candidates During the US Presidential Primary Season.” British Journal of Political Science 36 (03): 487. https://doi.org/10.1017/S0007123406000251.

Norrander, Barbara. 2010. The Imperfect Primary: Oddities, Biases, and Strengths of U.S. Presidential Nomination Politics. Controversies in Electoral Democracy and Representation. New York: Routledge.

Norrander, Barbara. 2015. The Imperfect Primary: Oddities, Biases, and Strengths of u.s. Presidential Nomination Politics. Second edition. Controversies in Electoral Democracy and Representation 12. New York, NY: Routledge. 
Pickup, Mark, and Richard Johnston. 2008. "Campaign Trial Heats as Election Forecasts: Measurement Error and Bias in 2004 Presidential Campaign Polls.” International Journal of Forecasting 24 (2): 272-84. https://doi.org/10.1016/j.ijforecast.2008.02.007.

Putnam, Josh. 2009a. “1988 Presidential Primary Calendar.” Frontloading HQ (blog). February 11, 2009. http://frontloading.blogspot.com/2009/02/1988-presidential-primarycalendar.html.

Putnam, Josh. 2009b. “2008 Presidential Primary Calendar." Frontloading HQ (blog). March 5, 2009. http://frontloading.blogspot.com/2009/03/2008-presidential-primarycalendar.html.

Rapoport, Ronald B., Walter J. Stone, and Alan I. Abramowitz. 1991. "Do Endorsements Matter? Group Influence in the 1984 Democratic Caucuses." The American Political Science Review 85 (1): 193. https://doi.org/10.2307/1962885.

Redlawsk, David P., Caroline J. Tolbert, and Todd Donovan. 2011. Why Iowa?: How Caucuses and Sequential Elections Improve the Presidential Nominating Process. Chicago ; London: University of Chicago Press.

Reuning, Kevin, and Nick Dietrich. 2016. “The Effect of the Media on the Invisible Primary." http://papers.ssrn.com/sol3/papers.cfm?abstract_id=2709208.

Ridout, Travis N., and Brandon Rottinghaus. 2008. “The Importance of Being Early: Presidential Primary Front-Loading and the Impact of the Proposed Western Regional Primary." PS: Political Science \& Politics 41 (01): 123-28. https://doi.org/10.1017/S1049096508080190.

Ripberger, Joseph T. 2011. "Capturing Curiosity: Using Internet Search Trends to Measure Public Attentiveness." Policy Studies Journal 39 (2): 239-259.

Schneider, Bill. 2007. “It Could All Be over after 'Super Duper Tuesday," February 7, 2007. http://www.cnn.com/2007/POLITICS/02/05/schneider.superduper.tuesday/index.h tml. 
Silver, Nate. 2014. "Is The Polling Industry Is Stasis Or In Crisis?” FiveThirtyEight (blog). August 25, 2014. https://fivethirtyeight.com/features/is-the-polling-industry-in-stasisor-in-crisis/.

Stanley, Harold W., and Charles D. Hadley. 1987. “The Southern Presidential Primary: Regional Intentions With National Implications." Publius: The Journal of Federalism 17 (3): 83-100. https://doi.org/10.1093/oxfordjournals.pubjof.a037661.

Steger, Wayne. 2013. "Polls and Elections: Two Paradigms of Presidential Nominations." Presidential Studies Quarterly 43 (2): 377-87. https://doi.org/10.1111/psq.12028.

Steger, Wayne P. 2007. "Who Wins Nominations and Why?: An Updated Forecast of the Presidential Primary Vote.” Political Research Quarterly 60 (1): 91-99. https://doi.org/10.1177/1065912906298597.

Steger, Wayne P. 2008. "Forecasting the Presidential Primary Vote: Viability, Ideology and Momentum." International Journal of Forecasting 24 (2): 193-208. https://doi.org/10.1016/j.ijforecast.2008.02.006.

Steger, Wayne P. 2015. A Citizen's Guide to Presidential Nominations: The Competition for Leadership. Citizen Guides to Politics and Public Affairs. New York: Routledge, Taylor $\&$ Francis Group.

Sullivan, John, and Michael Luo. 2008. "Romney Exits, Saying He Has to 'Stand Aside for Our Party." The New York Times, February 7, 2008. http://www.nytimes.com/2008/02/07/us/politics/07cnd-repubs.html.

Summary, B. 2010. “The Endorsement Effect: An Examination of Statewide Political Endorsements in the 2008 Democratic Caucus and Primary Season." American Behavioral Scientist 54 (3): 284-97. https://doi.org/10.1177/0002764210381709.

Swearingen, C. Douglas. 2017. "Public Attention and Fundraising in the Invisible Primary." In Midwest Political Science Association. Chicago, IL.

Swearingen, C. Douglas, and Joseph T. Ripberger. 2014. "Google Insights and U.S. Senate Elections: Does Search Traffic Provide a Valid Measure of Public Attention to Political Candidates?: Google Insights and U.S. Senate Elections.” Social Science Quarterly 95 (3): 882-93. https://doi.org/10.1111/ssqu.12075. 
Swearingen, C. Douglas, Elizabeth Stiles, and Kate Finneran. 2019. "Here's Looking at You: Public Attention in Presidential Primaries." Social Science Quarterly. https://doi.org/10.1111/ssqu.12671.

UPI. 1976. “Ford, Carter Head into Crucial Super Tuesday.” Lodi News-Sentinel, June 3, 1976. https://news.google.com/newspapers?id=Oe1fAAAAIBAJ\&sjid=YzIHAAAAIBAJ\& $\mathrm{pg}=6816,3038734 \& \mathrm{dq}=$ super-tuesday $\& \mathrm{hl}=\mathrm{en}$.

Washington Post. 2016. "Super Tuesday State Results," March 1, 2016. https://www.washingtonpost.com/2016-election-results/supertuesday/?utm_term $=.947 \mathrm{e} 18 \mathrm{~d} 4 \mathrm{~b} 6 \mathrm{~d} 8$.

Wendland, Jay. 2017. Campaigns That Matter: The Importance of Campaign Visits in Presidential Nominating Contests. Lanham, Maryland: Lexington Books.

Whitby, Kenny J. 2014. Strategic Decision-Making in Presidential Nominations: When and Why Party Elites Decide to Support a Candidate. Albany: State University of New York Press.

Zukin, Cliff. 2015. “What's the Matter With Polling?” The New York Times, June 20, 2015. https://www.nytimes.com/2015/06/21/opinion/sunday/whats-the-matter-withpolling.html. 


\begin{tabular}{|l|c|c|c|c|c|}
\hline Appendix: Descriptive Statistics & \multicolumn{5}{l|}{} \\
\hline Variable & Mean & Median & Std. Deviation & Minimum & Maximum \\
\hline Local Media Attention & 28.5 & 26.2 & 15.2 & 0 & 72.3 \\
\hline Public Attention & 28.5 & 23.0 & 21.0 & 0 & 82.7 \\
\hline Polling & 26.3 & 25.9 & 17.7 & 0 & 84.5 \\
\hline Prior Delegates & 28.1 & 26.6 & 22.5 & 0 & 65.2 \\
\hline Prior States & 28.5 & 25 & 28.3 & 0 & 100.0 \\
\hline Prior Caucus Wins & 1.3 & 1.0 & 2.12 & 0 & 11.0 \\
\hline Cash on Hand & 28.5 & 24.8 & 19.9 & -0.11 & 82.1 \\
\hline Disbursements & 28.5 & 28.7 & 16.6 & 0.28 & 61.4 \\
\hline Vote Share & 28.1 & 25.6 & 21.2 & 0 & 90.1 \\
\hline
\end{tabular}

